\title{
Technology-Based Communication Projects at an International College in Thailand
}

\author{
Hugh Fox and Desmond Lobo
}

\begin{abstract}
Budget constraints need not be an obstacle to infusing technology into the classroom curriculum, as in the past. This paper discusses how educational organizations can take advantage of free or online software, such as Comic Life, Prezi and Windows Movie Maker. Having taught the same courses before without the technology add-ons, we found that the infusion of technology into our classes was a positive one for both the instructors and the students.
\end{abstract}

Index Terms-E-education and e-learning technologies, photo novels, comic life, prezi, windows movie maker, animoto.

\section{INTRODUCTION}

During the last few years, our international college had put an emphasis on using more technology in the classroom. The challenge was how to add a technology component to existing Human Resources and Development (HRD) communication classes at an international college with a limited budget for technology. The solution was the identification of free tech tools including Comic Life, Prezi and Windows Movie Maker. The programs were used to infuse technology into existing HRD classes. The HRD major focus is communication and the decision was to use software to create products for communication. In particular, HRD training was the assumed goal of any product created. The instructors decided to explore free online programs or software available as a free download.

This paper is organized as follows. Sections II, III and IV describe in detail the classroom use of Comic Life (for creating photo novels), Prezi and Windows Movie Maker, respectively. Finally, a conclusion to the paper can be found in section $\mathrm{V}$.

\section{PHоTо Novels}

A photo novel is a type of comic book that uses photographs and some narrative text contained in a word balloon. These novels became quite trendy in the 1960s in Africa. Photo novels served as a means to tell movie-like stories, at a time when commercial cinema was not yet available on that continent. One of the most popular magazines featured the adventures of Lance Spearman, an African crime fighter. The magazine was widely read in countries such as Nigeria, Ghana, South Africa, Zambia, Tanzania, Kenya and Uganda. It is considered by many to be a distant forerunner of the current film industry of Nigeria.

Manuscript received January 7, 2012; revised March 9, 2012.

H. Fox and D. Lobo are with Burapha University International College, Thailand (e-mail: foxhugh@yahoo.com; DesmondLobo@yahoo.com).
[1].

In the 1970s, before the widespread use of home recording devices such as VCRs, photo novels became quite popular when several well-liked American television programs were adapted to this format. A scene from one of these programs, Star Trek, is depicted in Fig. 1.

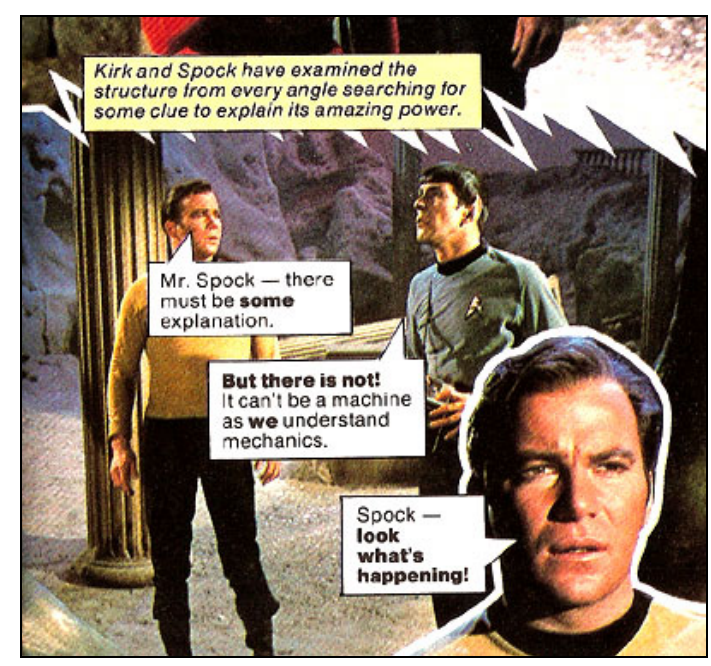

Fig. 1. Page from a Star Trek Photo Novel [2].

In more recent times, Kallol Das, from the Mudra Institute of Communications in India, made use of participatory photo novels to teach his marketing students [3]. He noted that teaching restless business students these days is not easy and found the photo novel approach an attractive communication medium. The students were more engaged when compared with the traditional lecturing strategy. After applying this method for teaching, Das confirmed an improvement in the students' understanding and knowledge, critical thinking, transfer ability, creative thinking, communication skills, and leadership ability.

\section{A. Comic Life}

Similar to the strategy that had been undertaken by Das with his marketing students in India [3], the students at our college were required to create a photo novel using Comic Life in an organizational communication class. Comic Life is a powerful comic book creator that includes bendable, authentic comic lettering text, drag-and-drop images from the integrated photo viewer or desktop, image filtering options for project photos, a library of pre-made templates, styles and fonts and Webcam / DV Cam image capture. The students were given time during class to go to the computer lab and download Comic Life. The instructors showed a YouTube video on how to use Comic Life. The assignment was to make a photo novel using the software.

A photo novel, as mentioned earlier, uses photos of actors and actresses instead of illustrations. The instructors 
provided materials designed by UNESCO [4]. UNESCO has created a handbook on how to create a photo novel for educational purposes. The audience of the handbook is NGOs and the handbook is 46 pages long and very detailed. The UNESCO handbook treats the creation of the photo novel as a photo shoot complete with detailed roles and an explanation of how to write a detailed script. In hindsight, this is not the best handbook for a class that has never done something like a photo novel before.

A more useful document is provided by Nimmon and Begoray [5]. The audience is classroom teachers and ESL students and describes a ten step process for making a photo novel in six pages. Both how-to photo novel guides are available for free online. Excellent examples of photo novels are provided by the Centre for Addiction and Mental Health (CAMH) in Canada [6]. CAMH has created photo novels that educate the reader on the topics of alcohol abuse, depression, drugs, gambling and post-traumatic stress disorders. The photo novels mentioned can all be downloaded online at www.camh.net.

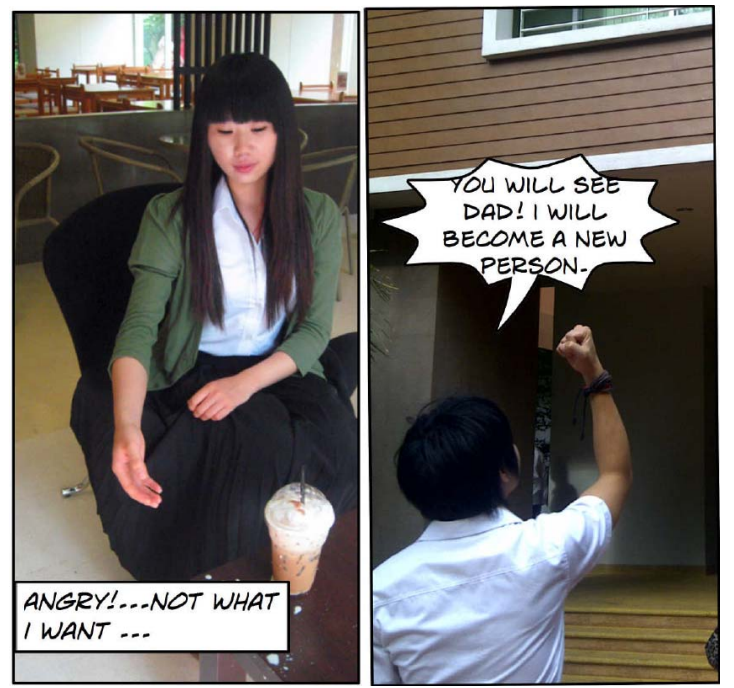

Fig. 2. Images from Student-Created Photo Novels.

The instructors had allotted approximately three hours for the students to 'learn' how to use Comic Life, but was surprised to see some of the students making effective comic books within an hour of being exposed to the software. A couple of images from some of these student-created comic books are provided in Fig. 2.

One student made a comic book named "Bored Dog" which described the boring life of her dog using images about her dog on Facebook! The comic strip was actually quite entertaining. We had this same student in writing classes and getting her to write even a paragraph in English had not been easy, but now this same student had produced a three page comic book with an introduction, some action and a climax (conclusion).

Nimmon had conducted some research about using photo novels with ESL populations [7]. This particular class was not an ESL class but did have a few native English speakers that were expected to create written products in all their classes in English. About half our students are Thai and about half our students are Chinese. Most of the students are avid readers of comic books. Unlike the West where the audience for comic books is largely male, both male and female students read comic books for fun in Asia. There may be a place for comic book creation using computer programs in writing classes in Asia in general. The technical side was much easier than the instructor anticipated. The instructor had not anticipated that Comic Life was 'free', but that there were detrimental details to this free usage.

The Comic Life software is free for only 30 days. After the 30-day limit you can still use the software, but the software leaves watermarks all over the comic book, making the comic virtually unreadable. If you download and install the software a second time onto the same computer, then the water marks remained. A single license costs 24.95 USD. A 25 seat license costs 199.00 USD. The software is relatively inexpensive if one considers that the software could be used in any number of EFL writing classes as a motivational tool.

There are various online comic book creators that really are free, although not as powerful and versatile as Comic Life. The other advantage of some of the online comic book creators is that they do not require the installation of special software such as Comic Life to be read on a computer. The instructor may use one of the online comic book creators in the future.

One of the better online comic creators is Strip Generator. In Strip Generator, the user can add unique human characters, beings, objects, shapes and speech bubbles with text, browse strips of other users rate and leave comments, and create as many strips as they like. It has a drag and drop interface. No registration is necessary; however, if registered, then the user will receive extra features. The user can print his or her strips or publish online and the user can share his or her strip by forwarding a link or embedding. Strip Generator is better suited for the creation of a single strip of three to four comic books panels rather than a full fledged comic book. On the other hand, the ability to create characters with online tools means no photography and therefore no actors or photographers, as is the case with photo novels. This means one student can make one comic strip rather than using a group of students.

The students of the international college are generally not native speakers of English and the same problems with grammar and spelling that the instructors routinely runs into in their writing assignments showed up in the comic books. However, the mistakes are much more noticeable in the relatively sparse text of a comic book. The instructors did want to show off the products of their class on the bulletin board next to their office, but decided the comic books needed some editing before such 'publication' was possible.

What had not been anticipated was that the students had a hard time understanding the difference between a comic book designed for entertainment purposes and one created for educational purposes. The CAMH model photo novels ended up being very important and perhaps in the future we would show the models first (examples of the end product) and the handbooks second. The instructors surveyed the students and found that the students had not been exposed to many educational comic books prior to taking this class.

A list of HRD topics was provided for all three technology and training projects. The students had an especially hard time picking a topic for the comic book project compared to 
the other two projects. There were 12 students and they broke into four groups ranging from groups of two to four students. The groups with fewer students made much better comic books than the larger groups. This project would be hard to do by a student alone. You need a photographer and an actor at the very least. The two-person group recruited 'actors' for their project and focused on acting as directors and photographers. For groups with four students, though, there was no need to recruit additional extras.

\section{PREZI}

The students were required to make a presentation using Prezi in a class about effective communication. Prezi creates a visual map and the presenter can zoom in and out of that visual map. Prezi excels at showing the 'big picture' overviews. In the past, the focus of this class had been on how to make effective PowerPoint presentations. Students have studied PowerPoint before in high school and in the first year computer literacy class, so this kind of class can be repetitive in terms of technology.

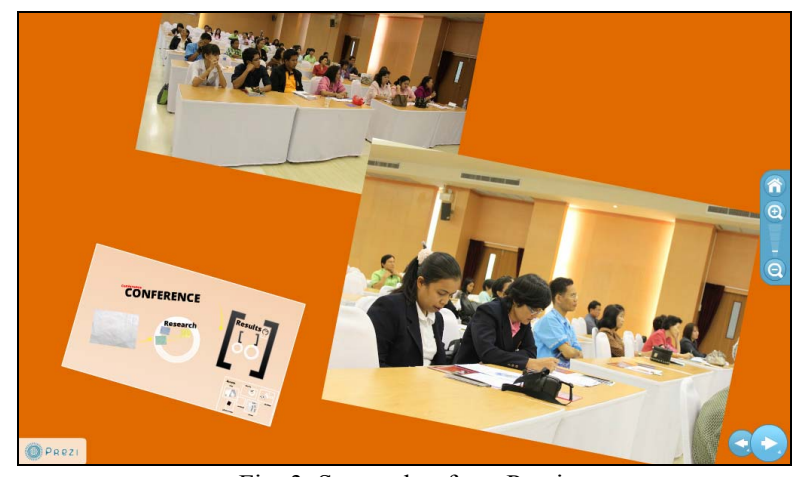

Fig. 3. Screenshot from Prezi.

Prezi is an online presentation software program that can be used instead of PowerPoint. The students had never used Prezi before but really liked it! We would say just about all the students felt that Prezi was more 'fun' than PowerPoint. The instructors had students in all three classes with technology projects and did ask them which project they liked the most; all of them agreed that Prezi was the most enjoyable. The zooming is very dramatic visually compared to the slide transitions in PowerPoint. Prezi was the easiest software to integrate into a class. As a totally online program, the student does not have to worry about installing software prior to using the program. The Prezi user just has to access their online Prezi account. This is not a problem at our college since the college has reliable Internet access in all the classrooms.

We were informed by other instructors that students had gone ahead and done Prezi presentations in their classes on their own. The other instructors were impressed by the results of the student's efforts. Prezi is also a program that can be easily used by a single student, just like PowerPoint. Prezi provides a software manual for free at their site, as well as a series of videos on their site on how to use Prezi. However, many students skipped the video and the manual and just started teaching themselves in an absolutely incredible amount of time. A screenshot of Prezi is provided in Fig. 3.
Rockinson-Szapkiw, Tucker, and Knight [8] suggest that Prezi may help instructors teach in a non-linear manner and may have cognitive advantages over PowerPoint. Prezi should not be seen as a replacement of PowerPoint, but as an alternative for subject matter that lends itself to a non-linear presentation as opposed to the topic/subtopic default of PowerPoint. The cognitive impact of Prezi as opposed to PowerPoint is a potential research project of great relevance.

\section{WINDOWS MOVIE MAKER}

The students were required to create a video on an HRD topic using Windows Movie Maker in a technical communication class. Despite the fact that Movie Maker is a free software program from Microsoft and our lab is licensed to use such software for free, the software was not installed on any of the computers in the lab. Classroom time was spent installing the software. About half the students in the international college are from China and occasionally the software program would show instructions for installation in Thai, presumably due to the fact that a Thai-English version of Windows had been installed on each of the computers in the lab. This language problem was quickly solved by having the Thai students help the Chinese students install the software. Later the Chinese students told us they had figured out how to install a Chinese version of Movie Maker on their own computers. A screenshot of Windows Movie Maker is provided in Fig. 4 below.

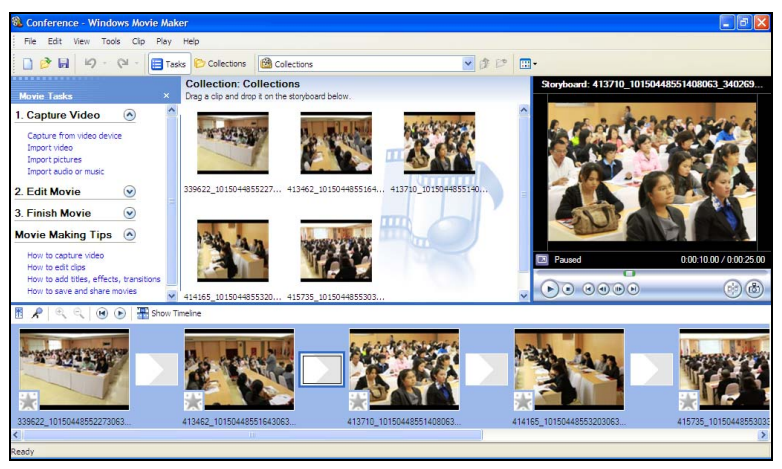

Fig. 4. Screenshot from Windows Movie Maker.

The students were broken into four groups of more or less five students in order to make an HRD training video. One video camera was provided by the instructors during lab days with the limitation that the camera had to be used during that period. The students all opted to use their cell phones instead. The instructors did point out the video quality and especially the sound would not be as good as when a cell phone was used instead of a video camera. The students still decided to use their own cell phones due to the convenience of such usage. Poor video was not a problem! The cell phones produced clear and crisp video. One of the student-made videos did have a problem with poor audio quality to the point that the quality of the project was not very good.

One of the more effective videos did not go the actor route at all and instead used pictures and PowerPoint slides in a montage with music to make their message about having a healthy diet. Some of the still pictures showed students eating and not eating the right foods. The students did have to add 
text to their videos in the form of a title and credits and this was not hard for the students at all. In order to avoid the sound problem and still teach the student how to use the editing power of Movie Maker, the instructors might opt to use montage type videos as their class projects.

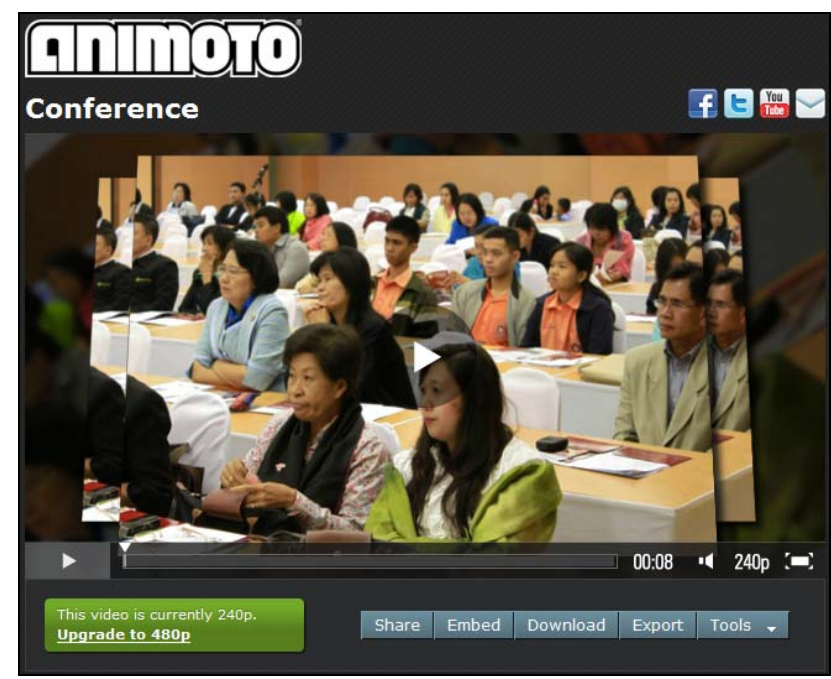

Fig. 5. Screenshot from Animoto [1].

Again, there is an online alternative to Movie Maker. JayCut is a powerful online video editor which has many of the same capabilities of Movie Maker. However, JayCut is not allowing new users to register. Another online video editor that allows users to create online slideshows is Animoto (a screenshot is provided in Fig. 5). Our students loved this program and made slideshows for their Facebook accounts literally within an hour. Animoto might be a good program for an instructor to introduce the student to video editing before moving on to the more powerful but harder to use programs such as Movie Maker and JayCut. Also, Animoto allows one student to make one project rather than necessitating a student group to do the project. If the instructor decides to go the video route then the number of online resources goes up exponentially. There are countless articles about making a classroom video. Not surprisingly, there are countless videos on using Movie Maker and making classroom videos. The biggest challenge is picking resources that fit the skill and English level of your particular class.

\section{CONCLUSION}

Budget constraints are no longer the obstacle to infusing technology into the classroom curriculum as in the past. Educational organizations can take advantage of online software or software that can be downloaded for free. The researchers learned three lessons from their experience:

Lesson \# One

The researchers found through this experience that online programs are especially handy since they can be used without having to worry about the often time consuming installation process.

Lesson \# Two

Prezi was the easiest program for the students to use for several reasons. Students understand what a presentation for informational purposes is already due to prior examples in other classes. Substituting PowerPoint with Prezi was not such a big conceptual leap. Using a comic book or video to train was something they had never done with any type of software. Students have been exposed to educational videos and there are many examples of such videos on YouTube. The students have not been exposed to that many examples of educational comic books and examples are not that readily available. Perhaps Comic Life would be better used in a creative writing class than a communication for training purposes class.

One student can do a Prezi project. Comic Life and Windows Movie Maker projects require a group of students. We would suggest that any instructor planning to add a technology-based communication component to their class should use Prezi as their first attempt in this area. The instructors put an emphasis on the products produced and not on using the products in simulated training situation. If the same students were to make a second product using the same tools, then the logical extension would be to focus on how the products can be successfully integrated into the training process rather than looking at the products as stand-alone products.

\section{Lesson \# Three}

There are less powerful but easier to use programs online that can act as substitutes for Comic Life and Movie Maker. Strip Generator is not as powerful as Comic Life, but is easier to learn and students can create products with far less class time and do not need to rely on a group. Animoto can act as a substitute for Movie Maker in a similar manner to Strip Generator. Animator is easy to use and the student can do a classroom project with far less time than with Movie Maker. The product is of a more limited nature but still introduces the students to the basics of video editing. There is transfer of both technical and cognitive skills from the less powerful but simpler to use programs such as Strip Generator and Animoto and in the future the researcher will use these programs first before moving onto the more powerful but harder to use programs like Comic Life and Movie Maker.

Some instructors may be more interested in giving students a 'taste' of technology, in which case Animoto and Strip generator are more appropriate. Some instructors may want the students to learn the technology involved in greater depth in which case Comic Life and Movie Maker are more appropriate. Overall, the infusion of technology into the three classes was a positive one for both the instructors and the students. We have taught the same classes before minus the technology add-ons and found that the technology made the classes far more relevant and enjoyable for the students and the instructors.

\section{REFERENCES}

[1] M. Krings, "A Prequel to Nollywood: South African Photo Novels and their Pan-African Consumption in the Late 1960s," Journal of African Cultural Studies, Special Issue: African Film and Video: Pleasure, Politics, Performance, Vol. 22 (1), 2010

[2] "To Boldly Go Where No Screen Capture Has Gone Before," Comics Oughta Be Fun, Retrieved from http://bullyscomics.blogspot.com, Dec. 2011

[3] K. Das, "Using Participatory Photo Novels to Teach Marketing," Journal of Marketing Education, Sage Publications, 6 December 2011 
[4] S. Dorance, "How to Create and Publish a Photo Novel," United Nations Educational, Scientific and Cultural Organization (UNESCO), 2008

[5] L. Nimmon and D. Begorah, "Creating Participatory Photonovels: A Classroom Guide," Adult Basic Education and Literacy Journal, Vol. 2 (3), Fall 2008.

[6] "Alcohol," "Depression," "Drugs," "Gambling" and "Post-traumatic Stress Disorder," Photo-Novella Health Promotion Project, Centre for Addiction and Mental Health, 2004

[7] L. Nimmon, "Within the Eyes of the People: Using a Photonovel as a Consciousness-Raising Health Literacy Tool with ESL-Speaking Immigrant Women," Canadian Journal of Public Health, Vol. 98 (4), pp. 337-340, 2007.

[8] A. Rockinson-Szapkiw, J. Tucker, and A. and Knight, "Prezi: Trading Linear Presentations for Conceptual Learning Experiences in Counselor Education,” Berkeley Electronic Press, 2011.

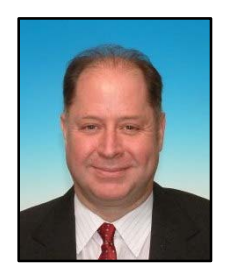

Dr. Hugh Fox is a member of IAENG. I was born in Champaign, Illinois, near the campus of Illinois State University, in the USA in 1957 while my parents were working on their doctorates. I have a bachelor's in Political Science from Michigan State University (MSU), which I earned in 1981. I also was certified in English as Second Language (ESL), Bilingual Education and Social Science at MSU during the same period. I have a master's in Ed. Psychology and Curriculum and Instruction from Texas A \& M University, College Station. I earned my doctorate in 1993. The dissertation topic for my doctorate was computer assisted-language learning (CALL) with a focus on ESL settings. My name is Hugh Fox III. My grandfather was a medical doctor and my father a widely published professor with the same first and last name, so I use the third in order to avoid confusion between us. I was an Associate Professor at Our Lady of the Lake University at Texas A \& M University in San Antonio, Texas until moving to Asia in
1999. I have been a professor in China, Taiwan, South Korea and Japan. I am currently a lecturer at Burapha International College located in Bangsean, Thailand. I have presented many times at Teaching English to Speakers of Other Languages Inc. (TESOL Inc.) and have journal publications in the areas of educational technology and ESL.

I have received several teaching awards at the various institutions I have worked at, including Our Lady of the Lake University. I was a Bilingual Fellow while working on my doctorate. I was a member of the CALL subcommittee of TESOL Inc. I am a member of the academic honorary society Phi Theta Kappa.

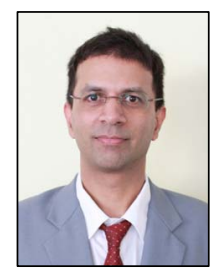

Dr. Desmond Lobo has a BSc degree (Computer Science for Data Management, Mathematics and Actuarial Science) from the University of Toronto in Canada, an MSc degree (Computer Science) from Coventry University in England and a PhD degree (Information Technology and Mathematics) from the University of Ballarat in Australia. He also obtained a professional actuarial qualification and is a member of the Society of Actuaries in the USA. Dr. Lobo has ten years of experience working as a university lecturer in Thailand, two years of experience working as an actuary for multinational companies, and four years of experience working for a Canadian public transport agency. He currently works as a lecturer at Burapha University International College in Thailand. Dr. Lobo is a senior member of both the IACSIT and the IEDRC. He has several international, peer-reviewed publications and his primary area of research is in the field of computer security. 